\title{
Den iscenesatte folkelighed
}

\section{Af Néstor Garcia Canclini}

Hoader »det folkelige« og hoad er "folkekultur"? Nëstor Garcia Canclini har i denne artikel sat sig for at dekonstruere begrebet „det folkeliger og beskrive den made, forskellige grupper bruger og misbruger begrebet pa: Han analyserer tre fremherskende idéer om folkelighed: Folkloristernes romantiske idé om det oprindelige, der blev odelagt af massekulturen, massemediemes popularitetsbegreb og endelig populisternes - baide de hojre-og venstreorienteredes - iscenesattelse af folkeligheden. Desuden ser han på to marxistiske skolers opfattelse af forholdet mellem de dominerende og undertrykte klasser og forskellige definitioner af folkelighed. Ligesom Anamaria Fadul argumenterer Canclini for nodvendigheden af en ny, twordiscipliner forskning, som opfanger kompleksitet og flertydigheder i forholdet mellem de undertrykte og dominerende og ser "det folkeliger som en tragisk komedie med modsatnin.ger og flertydighed snarere end on evigt fremadskridende episk forlalling. Artiklen er en forkortet udgave af kapitel 5 i Canclinis bog fra 1989: Culturas Hibridas - Estrategias para entrar y salir de la modernidad. Mexico: Grijalbo.

\section{Follkloristernes ide om det oprindelige folk}

Man troede lange, at massemedierne var den store trussel for folkekulturen. I virkeligheden begyndte homogeniseringen af Amerikas oprindelige kulturer lange for udbredelsen af radio og fjernsyn: Nemlig da kolonialisterne udryddede de etniske kulturer, foretog en voldelig omvendelse af mangfoldige trossamfund til kristendommen, dannede nationale stater, indforte étsprogsundervisning i skoleme og organiserede byområderne.

Det var heller ikke de elektroniske medier, der oprindeligt gjorde folkekulturerne til massekulturer, selvom nogle af de tidlige kommunikationsforskere drog den fejlshutning. Ifolge dem ville massekulturen komme til at erstatte det folkelige og det traditionelle. Man forestillede sig massemedierne som noget, der aftegnede sig indenfor de sociale strukturer, med en iboende logik, ligesom litteraturen og kunsten var det frem til midten af det 20. ärhundrede: En subkultur hvis skabne afgjordes af dens repræsentanters position og dens almene udbredelse. Kommunikationsforskerne var imponerede over den hastige udbredelse, aviser $0 \mathrm{~g}$ blade samt radio og fjernsyn fik blandt publikum, og troede derfor, at de kulturelle andringer var et resultat af, at massemediernes budskab kvantiativt fik storre gennemslagskraft. Idag placerer man de elektroniske medier som del af en ge- nerel udviklingstendens i de moderne samfund. Industrialiseringen, urbaniseringen, udbredelsen af almindelig undervisningspligt, samt den politiske og faglige organisering skabte en ny masseproget orden $\mathrm{i}$ det sociale liv fra omkring midten af det 19. århundrede, for pressen, radioen og fjernsynet dukkede op.

\section{Massekulturens historie}

Massckulturbegrebet opstår forst efter, at samfundene er blevet til massesamfund (masificadas). I Latinamerika må de andringer, de moderne kommunikationsmedier har skabt, ses i sammenhang mod dannelse af en national bevidsthed. Monsivais (1984) fastslär, at det var gennem radioen og biografen, mexicanerne larte at betragte sig selv som en enhed fremfor som en etnisk og geografisk opslittet befolkning. Måder at tale på og klade sig på, manérer og vaner, som for forekom fjerne og adskilte, samles i det sprog som medierne henvender sig på til masserne, der strømmer til byerne. Derved opnår masserne en falles folelse af national identitet.

Martín-Barbero (1987) går să vidt som til at sige, at de nationale projekter konsolideres takket vare modet mellem staterne og et folk, som er blevet oplyst gennem kommunikationsteknologien. At skabe et land er ikke kun et sporgsmal om, at det, der produceres $i$ en region, kommer frem til 
en anden. Det kraver også et fælles kulturelt og politisk projekt, et falles kulturelt forbrug. Derfor er det ikke tilficldigt, at mediernes integrative betydning falder sammen med udbredelse afen national populisme. For at fremme den nationale integration, så et land holdt op med at vare set land bestăende af flere lande var det afgorende, at radioen genoptog de mundtlige kulturer fra forskellige regioner og fastholdt den hverdagskultur, der tog form og spredte sig i de urbane områder. Salledes udtrykte biografen, og senere til dels fjernsynet, wideen om nationen som en folelse og noget hverdagsagtigt « (Martín-Barbero 1987)

I den tredie fase - efter den forste udvikling henimod et massesamfund, og den anden fase, fremskyndet af alliancen mellem medier og populisme - blev massekommunikationen drivkraften i en nyskabende udvikling. Mens produktionen industrialiseredes og de moderne forbrugsvarer - biler, hårde hvidevarer - vandt udbredelse, reklamerede fjernsynet for produkterne og påvirkede således forbrugernes smag. Den folkelige kunst, som havde vundet udbredelse og legitimitet takket vare radioen og biografen, ombearbejdedes med henblik på det publikum, som nu fik kendskab til folkloren gennem fjernsynsprogrammer.

Med tiden og æendringerne i massekulturens funktion andres betegnelserne: Massekultur, for masserne, kulturindustrier. Man ville kunne skrive en hel historie om den såkaldte massekultur i form afet register over de betegnelser, der blev forkastet. Det ville blive en imponerende fortalling, selvom den ikke omfatter mere 30 eller 40 år. I midten af dette århundrede talte man om massernes kultur, skont man hurtigt blev opmarksomme på, at de nye medier, som radioen og fjernsynet, ikke var noget masserne ejede. Det forekom mere rimeligt at kalde den kultur for masserne, men denne betegnelse varede kun sålange teorien om envejskommunikation blev fastholdt. Denne byggede på en idé om mediernes absolutte manipulation og opfattede masserne som de underkuede modtagere. Begrebet kulturindustrier, som blev brugt af Frankfurterskolens tilhangere, er fortsat nyttigt, når vi onsker at gore opmærksom på, at stadig færre kulturprodukter frembringes individuelt eller som hăndvarksarbejde og stadig flere produceres industrielt. Alligevel plejer denne tilgang at sige for lidt om hwad, der produceres og hord der sker med modtagerne.

\section{Massemedierne: konstruktion af tilskueren}

De elektroniske medier viser en bemarkelsesvardig sammenhang med de traditionelle folkekulturer, sã vidt som begge er dramatiseringer af det sociale liv. Man skal ikke se sådan på det, at folkloren prasenterer en autentisk virkelighed, som så bliver forvansket af medierne. Eventyrenes romantiske idealisering minder meget om telenovelaerne, fascinationen af skrxakfortallinger er ikke fjern fra den, som kriminalserierne spiller på (og man ved jo at det er dén genre i blade og fjernsynsprogrammer, der har storst folkelig gennemslagskraft). Melodramaets narrative strukturer, den sorte humor, konstruktionen af helte og antihelte og fortallinger om overnaturlige begivenheder, er andre af de mange ligheder, der gor den såkaldte massekultur til folklorens store konkurrent.

Det lykkes massemedieme at »behandle eventyr, foljetoner, mysterier, fester og humor, alt $\mathrm{i}$ alt omräder, der er ilde set af den dannede kulturk (Ford 1988:36-38) og inkorporere dem i den hegemoniske kultur med en kraft, som folkloren aldrig ville have kumnet. I alle latinamerikanske lande iscenesxtter radiocn, og i nogle biografen, folkets sprog og de myter (mitemas), som aldrig kom til orde i den dominerende maler-og fortallekunst. eller musik. Men samtidig knytter radioen og biografen det folkelige sammen med det traditionelle, det moderne, historien og det politiske.

Hvilken betydning har folket for en leder af $\mathrm{cn}$ fjernsynskanal eller en markedsanalytiker? Ikke andet end lyttertal, gennemsnitigt antal solgte plader pr. måned, statistikker, som kan forevises annoncorene. For medierne er det folkelige ikke et resultat af traditioner, ej heller af den kollektive "personlighed «, det defineres heller ikke udfra dets manuelle, kunstneriske, mundtlige, kort sagt premoderne karakter. Kommunikationsforskerne ser den nutidige folkelige kultur som noget, der er grundlagt fra og med de elektroniske medier. Ikke som et resultat af lokale forskelligheder, men derim mod som resultat af kulturindustriens på én gang spredende og integrerende virkning;

\section{Det folkelige og det populaere}

Betegnelsen »folkelig « er skabt af medierne, den folger markedslogikken. "Det folkelige« er det som sælger massivt, det som folkemangden synes om. I virkeligheden betyder det ikke noget for marked- 
et og for medierne, om noget er folkeligt (popular), men om det er populart (la popularidad). De bekymrer sig ikke om at bevare dct folkelige som kultur og tradition; fremfor skabelsen af en historisk hukommelse interesserer det kulturindustrien at skabe og forbedre den simultane kontakt mellem sendere og modtagere. Den finder også mishag i ordet spueblok (folket), som fremmaner billeder af vold og opstande. Forskydningen af substantivet folk (pueblo) til adjektivet folkelig (popular), og yderligere til det abstrakte substantiv poularitet (popularidad) er en neutraliserende forskydning, der kan bruges til at kontrollere folkets "politiske påvirkelighed « (Bolléme 1986). Mens folket kan vare arnestedet for optøjer og fare, or popularitel - knyttet til en orden og ct vardisystem - målt og reguleret af opinionsundersøgelserne.

I en politisk manifestation er folkets reaktioner uforudsigelige, hvorimod en sangers eller skuespillers popularitet, indenfor et lukket område et stadion, en fjernsynskanal - med programmeret start og afslutning, på pracise tidspunkter, er en kontrolleret form for underholdning. Folket (el pueblo) synes at vare et subjekt, der fremstiller sig selv, mens populariteten (la popularidad) er den ekstreme form for genfremstilling, den mest abstrakte, som reduceres til et sporgsmål om tal og statistiske sammenligninger.

For markedet og for medierne har det folkelige ingen betydning som bevaringsvardig tradition. Tvertimod, loven om den uophørlige foraldelse har vannet os til, at det folkelige, i betydningen populare, netop fordi det cr succesfuldt, også er noget flygtigt, der glemmes. Hvis det, som salger ét år, blev ved med at have succes ăret efter, ville de nye plader og jeans ikke kunne salges. Det virkeligt populæere er dét, som ikke varer ved, det ophobes ikke som en erfaring, det opnàede skaber ikke rigdom.

Kommunikationsforskernes definition af rdet folkelige forkaster også dets ontologiske karakter, som folkloren ellers tildeler det. Det folkelige betegner her ikke hvad folket er eller har, men hvad det har tilgang til, kan lide, fortjener at fâ del i eller bruger ofte. Săledes skabes en forvridning af begrebet, der gor det til folklorens modsatning: Det folkelige i betydningen det populare er tildelt folket udefra. Denne heteronome måde at definere den underordnede kultur pă, er til dels skabt af mediernes allestedsnærværelse. Vi er stadig ikke kommet ud over kommunikationsforskernes stirren sig blind på fjernsynets hastigt voksende seertal i den periode, hvor det gjaldt om at tiltakke så stort et publikum som muligt. Det er pudsigt, at denne tro pa mediemes ubegransede evne til at danne forskrifter for social opforsel fortsat prager kritiske forskere i demokratiske kulturorganisationer. Medierne beskyldes for at bortlede massernes opmarksomhed fra deres egen virkelighed. En stor del af litteraturen reducerer massekommunikation til et sporgsmål om, hvordan et transnationalt system pătvinger den underordnede klasse bestemte holdninger og smag.

\section{Folkekulturen er ikke passiv}

Fra 60'erne og frem er der teoretisk og empirisk blevet stillet sporgsmalstegn ved opfattelsen af det folkelige som en domineret, passiv og genspejlende enhed. En sådan opfattelse kan ikke fastholdes i lyset af den postfoucault'ske opfattelse af magten. Ifølge denne betragtes magten ikke langere som nogle oppefra påforte institutionelle strukturer, men derimod som spredte sociale relationer, Magten er ikke indbygget $\mathrm{i}$ en institution, ej heller $\mathrm{i}$ Staten eller massemedieme. Magten betragtes heller ikke som en sarlig kraft, nogle enkelte er blevet udstyret med: "det er benavnelsen for en strategisk situation i et givet samfund « (Foucault 1977). Ogsa de dominerede dele af befolkningen (de sâkaldt folkelige sektorer) bidrager til magtforholdene, der opstår parallelt i produktionen og i forbruget, i familierne og blandt individer, på fabrikken og i fagforeningen, i partiernes ledelse og i basisorganismerne, i massemedieme og i de receptionsstrukturer, der tilegner sig og genfortolker deres budskab. Lad os forestille os en folkefest, som for eksempel ceremonien for de døde eller karnevallet er det i llere latinamerikanske lande. De opstod som falles højtideligholdelser, men pă et tidspunkt begyndte der at komme turister, derefter pressefotografer og flere turister. De lokale arrangerer opstiller boder, hvor der salges drikkevarer, kunsthandvark, som de altid har produceret, souvenirs, som de finder på for at udnytte de mange menneskers besog. Dertil kommer, at de tager betaling for at tillade fotografering og filmatisering. Hvor ligger magten? Hos massemedierne? Hos de lokale festarrangorer? Hos dem, der sælger drikkevarer, kunsthåndvark og souvenirs? Hos turisterne og tilskucme, som, hvis de holdt op med at interessere sig for ceremonierne, ville undergrave hele processen? Her er det tydeligt, at magten over den mảde, som begivenheden er byg- 


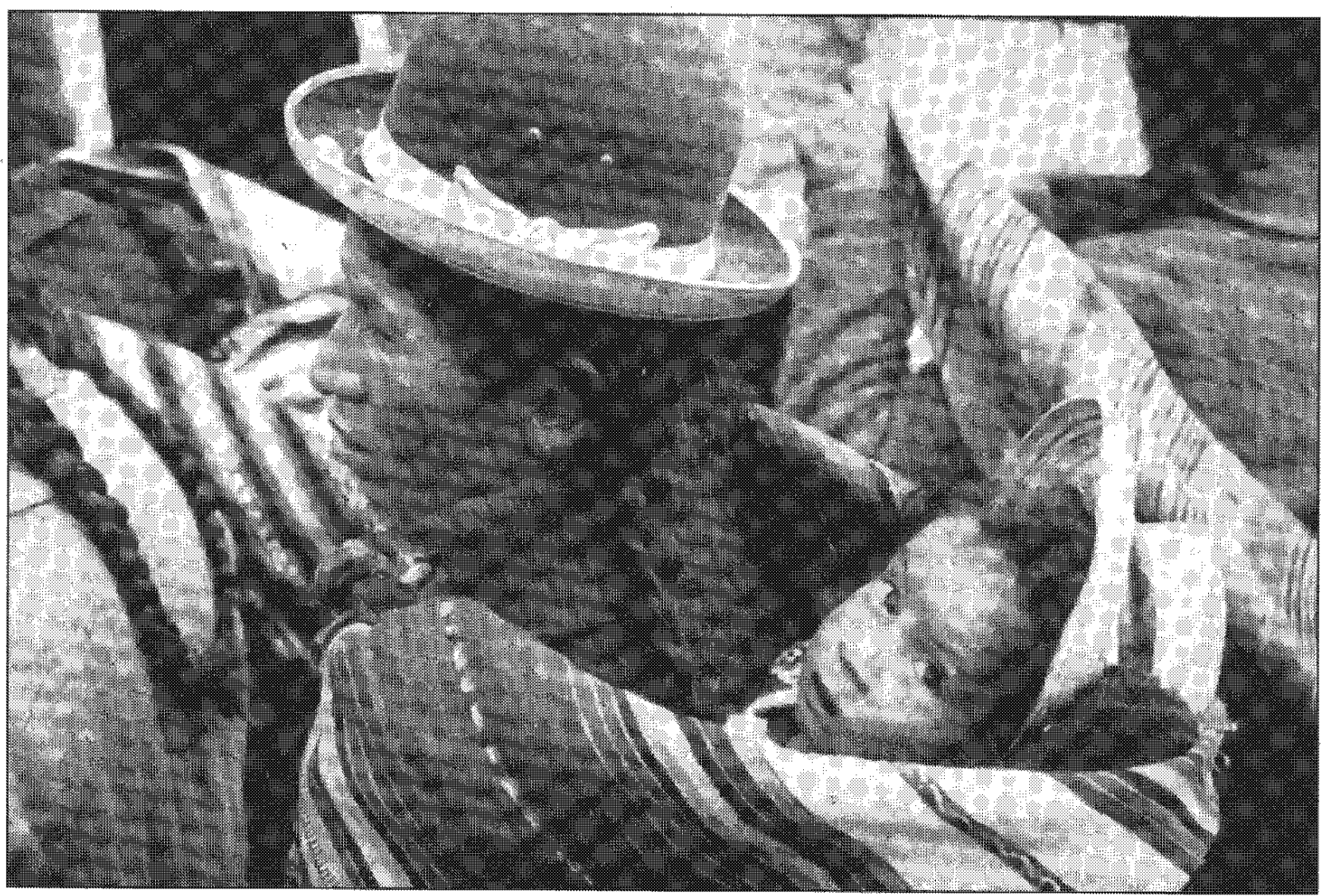

Latinamerika er et multietnisk samfund preget af mange forskellige kulturer.

get op på, er et resultat af et komplekst netvark bestaende af nyfortolkede traditioner, moderne indflydelse og et vald af aktorer.

Bindeleddet mellem medierne og folkekulturen har de sidste par årtier varet del af bredere strukturer for social interaktion. For at forsta disse bindeled må vi bevage os fra »medier til mediering« fastholder Martín-Barbero, idet han analyserer radioen fra $30^{\circ} \mathrm{erne}$ til $50^{\prime} \mathrm{erne}$ og dens indflydelse på en udvikling, hvor masserne blev til et folk og folket til en Nation. Det samme sker, hvis man studem rer biografens virkning på urbaniseringsprocesserne. Filmene hjalp immigranterne med at lare at leve og klare sig $\mathrm{i}$ byerne, med at tilpasse deres moral og deres myter. Radioen »nationaliserede sproget«, fjernsynet sammensmelter indtrykkene og viser et billedrepertoire, hvor det nationale forenes med det internationale (Martin-Barbero 1987a).

\section{Reception af mediernes budskaber}

Kommunikationsteknologien og kulturindustrien erstatter ikke traditionerne, men andrer istedet modtageligheden samt betingelserne for at opnå og forny viden. De skaber en anden slags tilknytning mellem kultur og sted, mellem det lokale og det internationale, samt nye værktojer til bearbejdning af erfaringer $0 \mathrm{~g}$ disses betydning. De omformer sammenhængen mellem fiktion og virkelighed. Alt dette stammer fra de kulturelle andringer, som kommercialiseringen medførte, selvom de navnte kulturelle andringer ikke kan forklares udelukkende med den okonomiske påvirkning.

Massemedierne iscenesatter det folkelige på en ny måde, men det interessante er, at vi stort set står uvidende overfor, hvordan folket reagerer på denne andring. Nok er mediernes almagt efterhånden modbevist, men vi mangler stadig viden om, hvilken rolle medierne spiller i forhold til andre betydningsdannende systemer, såsom kulter og folkelige traditioner. Det er ikke nok at antage, at diskurserne modtages på forskellige măder og at der ikke findes entydige og direkte sammenhærige i betydningscirkulationen. Massemediernes diskurs skaber et betydningsfelt sammen med andre sociale formidlere, et betydningsfelt, der ikke kan forståes udelukkende udfra produktionsstruktum ren, men krever en undersagelse af medierings- 
processerne samt de forskellige diskurser og deres betydning (se feks. Verón 1987 for et solidt teom retisk udkast til en ikke-lininear måde at analysere betydningsdannelsen i komplekse samfund). Men manglen på studier af kultur- og medieforbruget, udover kvantitative markeds- og meningsundersøgelser, muliggor kun små fremskridt i studiet og beskrivelsen af forholdet mellem massemedieme og seernes reception.

Alligevel er det ct velegnet område for et transdisciplinart arbejde. Det er et kommunikationssporgsmål, der kraver mere hårfine metodiske begreber og instrumenter end dem, der sæedvanligvis benyttes i publikums- og markedsundersow gelser. Antropologiske metoder og teorier om mikrointeraktionerne i hverdagslivet kan bidrage til undersagelser af, hvorledes mediernes diskurs indlemmes i kulturhistorien, i folks betydningsdannelse og receptionsmonstre.

\section{Populisme: Skuespillerens forstillelse}

Der findes både sociologiske og politiske studier af populismen, men sjaldent omhandler de det centrale sporgsmål, nemlig dens måde at bruge kulturen til at opbygge magten. To centrale trak i populismens kulturelle praksis har interesse her: Den moderniserer folkekulturen ved at gøre den til et grundlaggende element i den samfundsmæssige orden og konsensus og samtidig har den en tilbøjelighed til at gore folket til rene tilskuere.

Til forskel fra folkloristikkens forherligelse af traditionerne, som skulle jene til at skabe en myte om folket som en oprindelig og skabende kraft, valger populismen dét fra fortidens kultuw relle skatkammer, som er foreneligt med den moderne udvikling. Kun fundamentalistiske grupper fastholder, at det folkelige handler om kxerlighed til jorden og racen som for industrialiseringen. De politiske populister benytter også en oprindelighedsideologi, men de tilpasser den til aktuelle konflikter. I statspopulismen påtager Staten eller en karismatisk leder sig at reprasentere folkets traditionelle vardier. Săledes legitimerer populisteme den orden, de administrerer, og giver folket tilliden til, at systemet indbefatter og ancrkender det (Portanticro og de Ipola 1987, Vega Centeno 1985).

Denne iscensattelse af det folkelige har varet en blanding af deltagelse og blandvark. FraVargas og Peron til nutidige populister går fremhavelsen af de underste klasser, forsvaret af deres arbejdsrettigheder, udbredelsen af deres kultur og kunst hănd $i$ hånd med imaginare iscenesattelser af deres reprasentation. Populismen gav de dominerede klasser mulighed for nye interaktionsformer i det moderne samfund, săvel med Staten som med andre hegemoniske aktorer. Denne interaktion bevirker at deres krav om arbejde, bolig og sundhed bliver delvist hort, at de undertrykte grupper larer at omgåes funktionæerer, blive sagsbehandlet, tale i radio og fjernsyn og i det hele taget stå frem. De nye borgere opnår en rolle ; magtens asymmetriske relationer, som en slags ritualisering, der til tider kommer til at erstatte selve interaktionen og opfyldelsen af de materielle krav. I denne proces er en overensstemmelse mellem den politiske populisme og kulturindustrien vigtig. Populisterne tager højde for, at folket eksisterer som en masse i de moderne samfund, som publikum for et kulturelt produktionssystem, der er nået udover sin håndvarksmassige fase og forsoger at forhindre at folket bliver passiv modtager af kommunikation. Deres kulturprogram går - udover at fremme de premoderne kommunikationsformer og politiske alliancer gennem direkte relationer til personer og bykvarterer - ud på at skabe politiske scener, hvorpå folket dukker op som deltagere (protestdemonstrationer, optog, massedyrkelse af riter).

\section{Den svakkede populisme}

I de senere år er der sket andringer, der har svakket denne konstituering af det folkelige. En af dem er skabt af kulturindustrien. Som andre produkter, făr de, der tilbydes på den politiske scene, en ny betydning gennem medieringen, hvor de underkastes reklamebranchens logik i jernsynet, radioen og pressen. At medvirke i en valgkampagne koster millioner af dollars og kraver kandidaternes tilpasning til det image, opinionsundersagelserne anbefaler, og stilisering af det politiske budskab og indhold. Plakaterne, en af de senere genrer indenfor den politiske diskurs, som indtil fornylig foregav at vare en whemmelavet og personlig kommunikationsform, er idag designede af reklamebureauer og hængt op på bestilling. Dette er mäske det tydeligste tegn på, hvorledes markedsforingsteknikker har erstattet den aktive og direkte sociale deltagelse. Da sådanne teknikker (en ansigtsloftning til kandidaten for at forbedre udseendet, skift af briller og beklædning, samt det 
gebyr, kommunikationsforskcme kræver for at rådgive) udbredes af medierne som en del af valgkampagneforestillingen, opstår der utrovardighed omkring den populistiske demagogi. Dette tab af troværdighed forstærkes yderligere med faldet $i$ valgdeltagelsen samt med partiernes troværdighedsproblemer på grund af deres manglende evne til at bekxmpe de økonomiske og sociale kriser.

En anden ændring, der svakker populismen, er netop den akonomiske krise og den neoliberale reorganisering af Stateme. Hvorledes iscenesatte folkets krav, når der ikke er et overskud at fordele? 80 'ernes stagnation og tilbagegang, den konstante nedskrivning af valutaen samt udenlandsgaldens pres skabte en indkomstnedgang til et niveau, der svarede til årtiet for. Udover at forvarre fattigdommen ødelagde arbejdslesheden og de udækkede basisbehov populismens symbolske spil og politiske dramatiseringer over folkets håb og forventninger.

Inxsten alle latinamerikanske samfund går den faldende interesse for at deltage aktivt i partipolitik hånd $\mathrm{i}$ hănd med faldet $\mathrm{i}$ oplaget for politiske ugemagasiner. Faldet i oplag skal ses i sammenhæng med, hvor meget, der blev trykt i 70 'crne. Derimod får blade med nyheds- og underholdningsstof flere lasere. I disse blade koncentreres det sociale og politiske stof til interviews fremfor analyser og til beskrivelser af de kendte personers liv og vaner fremfor af deres holdninger til konflikter, der berorer den almene borger. Således kan tidsskrifteme samt radio- og fjernsynsprogrammerne formidle på en venlig og underholdende måde, der tilfredsstiller forskellige forbrugsgrupper, samtidig med, at de undgår at problematisere samfundets sociale strukturer. Den politiske mæeling mellem folkelige bevagelser og regerings- $\mathrm{cl}$ ler partisystemet erstattes af den symbolske mægling, pressen og mediemes informative programmer udgor. Medierne simulerer, at vi inform meres. Når problemerne forekommer uloselige og de ansvarlige virker uduelige, tilbyder medierne kompensation i form af information, der er så intens, umiddelbar og hyppig, at den giver os en illusion om at deltage.

Disse forandringer har at gore med udviklingen fra en produktionskultur til en spekulations- og underholdningskultur. Den klassiske populisme baserede $\sin$ insisteren på det folkelige, på arbejderkulturen. Den teknologiske udvikling, der reducerer arbejdskraftbehovet og dekvalificerer arbejdernes tekniske kumnen, styrker arbejdsgiverkontrollen over produktionsprocessen og arbejdsforholdene. Således far det faglige system og de politikere, der fokuserer pă sociale aspekter fremfor teknologiske, svakket deres indflydelse. Den populisme, der overlever dette skift, forrykker sig så til forbruget (billigere varer i butikkerne og billigere statslige transportmidler) eller til symbolske tilbud: underholdning med kollektiv identifikation og garantier om orden og stabilitet.

\section{Den romantiske søgen efter det folkelige}

Men er det folkelige ikke andet end en slags iscenesattelse? Hvad gemmer der sig bag alle disse bugtalere, bag alle dissc forsøg på at lade det folkelige komme til udtryk bl.a. gennem film, teater mv? Moderniteten, som skabte disse »skabere af det folkelige«, gav samtidig mulighed for at komme bort fra denne teatralske cirkel: At tage ud til folket, lytte til det og se det handle. Lad os lase dets tekster, lad os deltage i dets spontane manifestationer, lad folket fa ordet. Lige fra romantikken i det 19. arhundrede til forfattere, der gør sig til journalister, til offentlige eller andre organisationer, der har til opgave at viderfore den mundtlige tradim tion, til romanforfattere med båndoptagere og laxrere, der grundlægger folkelige aviscr - alle disse gor forsøg på at give folket stemme, folket skal ikke repræsenteres, men præsentere sig selv. Livshistorier, fortallekonkurrencer, kroniker og vidnesbyrd, litteræe værksteder med arbejdere og bonder har sagt at give det folkelige mele en plads i den skreme verden, således at hverdagens diskurs i småstader og bykvarterer får en »legitim《 plads i kulturen.

De tre sektorer, vi her har analyseret: folkloristerne, massemedierne og de populistiske medier, bidrager til tider til den proces, det er at fa folket til at tale: De samler fortallinger, medtager gaw deinterviews i radio- og fjernsynsprogrammer og inddrager folket på magtens scener. Vi kan ikke vurdere dem alle på samme vis. Der er etnologer og historikere, der diskuterer de nødvendige metodiske betingelser for registrering og fortolkning af livshistorierne. Den mest avancerede debat finder sted indenfor den postmoderne amerikanske antropologi, som forsoger at vise, hvorledes forskeren altid intervenerer $i$ det samfund, han studerer, ved at skjule den fragmentariske karakter, enhver erfaring fra felten giver; samt hvorledes etnografiens tekstlige strategier reducerer enhver kulturs 
nuancer og modsatninger med den videnskabelige beskrivelses ensidighed. (se feks. Clifford og Marcus 1986 og Rosaldo 1989).

Men kravet om det folkelige udviklede ogsă andre bevagelser. I forste omgang dem, de laveste klasser selv skabte: Fra de politiske partier og fagforeninger til en omfattende samling af etniske, økologiske, feministiske, kunstneriske, alternative politiske grupperinger. Men denne mangfoldighed af reprasentanter, definitioner og inddelinger efter politiske eller sociale krav bidrager ikke til at præcisere, hvad vi forstår ved folkelig. Endnu mindre da betegnelsen wfolkelig er noget, fraktioner af en bevagelse kappes om med partier, fagform eninger eller Stater, der alle onsker at kalde sig folkelige.

\section{Den venstreorienterede populisme}

Den venstreorienterede eller alternative populisme bidrager også til at skabe uvished. Jeg tænker på bevægelser, der søger at efterligne de undertrykte klassers lingvistisk-kulturelle vaner og tror de rammer essensen af det folkelige med deres kritiske bevidsthed og samfundsandrende drivkraft. Denne tendens tog form i Brasilien og i andre latinamerikanske lande fra 60 'erne og frem. Forfattere, filmfolk, sangere, faglaerte og studerende samlet i Folkelige Centre for Brasiliansk Kultur (Centros Populares de Cultura brasileira) ivarksatte et enormt opsogende kulturarbejde og ondefinerede kultur til bevidstgørelse (concientización). I en bog, der samler de politisk-zestetiske ideer bag CPC skriver Ferreira Gullar: sDen folkelige kultur er, kort sagt, bevidstgorelsen om den brasilianske virkelighed (..) Den er, frem for alt, en revolutionær bevidsthed (Gullar 1980:84).

I slutningen af samme årti opfandt Gruppen til Biografens Befrielse (El Grupo Cine Liberación) i Argentina - og senere $i$ andre lande - handlingsbiografen (Cine acción), som nedbred publikums passivitet og fremmede deltagelsen. Den gik op imod den kommercielle og traditionelle biograffilm og imod peronismens hojreorienterede kulturindustri, der begransede sig til at ritualisere det folkelige som en mystisk kraft. Gruppen var fortaler for den "militante biograf , men samfundsomstyrtende kultur og wkampen for den nationale frigorelse (Solanas og Getino 1979: 29). I modsatning til »den undvigende biograf* prasenterede de »biografen, der genvinder virkelighe- den«, overfor »den passiviserende biografk, »agressionsbiografen «, og overfor »den institutionaliserede biograf«, »guerillabiografen « (Solanas og Getino 1979:49). Ligesom CPC brugte de betegnelsen folkloristisk om det folkelige: I stedet for at definere det udfra dets traditioner, definerede de det udfra dets andringspotentiale; i stedet for at forsoge at bevare kunsten, forsogte de at bruge den som agitationsredskab.

Denne opfattelse af folkekultur findes stadig i produktionsgrupper, $i$ kunstnerisk og politisk arbejde og $i$ alternativ uddannelse. Ifolge et register fra Latinamerikainstituttet findes der over tusinde af sădanne grupper på vores kontinent (for en opsamling $o g$ analyse af nogle af de alternative erfaringer, se f.eks. Canclini og Roncagliolo 1988). Mange af dem har - udover undervisning og mobilisering af folket til forsvar for sine rettigheder virkelig udbredt et empirisk kendskab til folkekulturen. I nogle lande endda mere end de akademiske institutioner har formået. Men deres politiske og sociale aktiviteter har som regel kun kort rakkevidde. Og de har ofte problemer med reelt at opstille alternative muligheder, fordi de viderforer en fejlagtig opfattelse af folklorisme og populisme. De forestiller sig, at en mangfoldiggorelse af smàgruppernes handlinger en dag vil medfore en generel samfundsandring, uden at tage $\mathrm{i}$ betragtw ning, at det er i kulturindustrien og Staten, som virkelig influerer på den folkelige sektors tanker og bevidsthed, at de folkelige interesser skal reprascnteres. De isolerer små grupper i troen på at generobre utopien af letgennemskuelige og ligebyrdige relationer med det simple kunstgreb at frigøre de undertrykte klasser fra de udefrakommende kræfter (medierne, den burcaukratiserede politik) som korrumperer dem, og derefter lade den mennekelige naturs iboende godhed komme frem.

Med aktions-forskning og deltagelsesmetoder foregiver de at have den wsande forklaring af det folkelige, men deres mikrosociale analyser (af boligområder og hverdagsliv) er afskăret fra samfundets makrorelationer, der betinger det mikrosociale, og gor det umuligt for dem at forklare, hvorfor det folkelige bliver restruktureret $\mathrm{i}$ kulturindustriens epoke. Iscenesattelsen af de mautentiske « »basis «sektorer, som on de var autonome og ubererte af de makrosociale strukturer, lukker for enhver problematisering af den folkelige bevidstheds agthed og gyldighed. De anvender heller ikke epistemologiske metoder, der kunne stille sporgsmal ved den naive vished om den folkelige 
fornuft. De går udfra, at det at give folket ordet er nok til, at den sande viden kommer frem. Da et sådant arbejde heller ikke indbefatter en kritisk reflektion over egne forskningsmetoder (forholdet mellem forsker og informant), overfores deres egne politiske utopier pă studieobjektet. De ser kun hand linger, der stiller sporgsmålstegn ved det eksisterende og fortolker den kulturelle forskellighed som modstand.

Det er vigtigt, at både forskerne og informanterne er kritiske overfor etnocentrisme. Vi, der har interesse $\mathrm{i}$ at udvikle det intellektuelle felt, såvel som de, der kombinerer studier og politisk handling (som forholder sig både til den akademiske og den politiske verden) og folket selv, vi er alle underlagt en tendens til at udvikle opfattelses- og forståelsesskemaer, der retfirdiggør vores egen sociale placering. Viden skabes ved at bryde med vores forhåndsviden og ved hjolp af almindelig, sund fornuft, om den så er folkelig, politisk eller videnskabelig.

\section{Henimod en transdisciplinæer forskning}

Vi har påvist forskellen pă tre måder at anvende og forstå betegnelsen »folkelig « på. Folkloristerne taler nasten altid om det traditionelt folkelige, massemedierne om folkeligheden og politikerne om folket. Vi har identificeret nogle sociale strategier som er tilstede $i$ alle tre betegnelser. Vi har set uoverensstemmelserne mellem dem - deres forskellige verdensopfattelser og vidensanvendelse, hvilket placerer studiet af det folkelige i en praparadigmatisk position. Giver det mening, med benzvnelsen det folkelige at omslutte så divergerende udtryksformer, som dem folkloristerne, antropologerne, sociologerne og kommunikationsforskerne studerer og som politikerne, fortallerne og underviserne taler om? Hvad er den videnskabelige fordel ved at tildele indianerkulturen, arbejderkulturen, bondekulturen og bykulturen falles-betegnelsen folkelig kultur, når de hver for sig er betinget af så forskellige arbejdsforhold? Disse sporgsmål har fundet institutionelle og kommunikationelle svar fremfor videnskabelige losninger. Man samler en gruppe heterogene artikler eller man organiserer en multitematisk konference under fellesoverskriften »den folkelige kultur«. Man benytter betegnelsen om et museum eller et fjernsynsprogram, hvor man forsoger at vise et lands forskellige kulturer. Noget sådant sker, når man organiserer »folkelige bevagelser og under denne benavnelse anbringer grupper, som nok alle tilhører de lavere klasser, men har forskellige etniske tilhersforhold (indianerne), placering i produktionen (arbejderne) eller geografisk tilhorsforhold (bonder eller byfolk). Ideen om det folkelige tillader pa kunstig vis at samle underordnede grupper og tildcle dem et falles solidarisk projekt, en frelles identitet.

Indenfor samfundsvidenskaben har denne forskelligartede anvendelse af betegnelsen »folkelig * også haft positive virkninger. Fra udelukkende at bruge betegnelsen om traditionelle befolkningsgrupper og indianere, opdagede man andre kulturelle aktører og udtryksformer, der deler betingelseme som underordnede med de traditionelle befolkningsgrupper. Dette frigjorde det folkelige fra den økonomistiske kurs, der reducerede betegnelsen til et sporgsmål om klassetilhorsforhold. Selvom klasseteorien fortsat er nodvendig for at karakterisere de underordnede klasser og deres politiske kamp, gor en begrebsudvidelse det muligt at omfatte kulturelle fremstillingsformer og sociale bevegelser, der ikke stammer fra deres placering i produktionsforholdene. Betegnelsen folkelig har giort det nemmere at studere de underordnede grupper, ikke kun i form af arbejdere og politisk aktive, men også som jord»besattere《 og forbrugere.

\section{Forsog på at definere det folke- lige: reproduktionsteorien og Gramscis hegemoniteori}

Men både politikere og videnskabsfolk har brug for en mere pracis empirisk referent. Vi har brug for at vide, om det folkelige er en ideologisk konstruktion, eller om det henviser til virkelige og identificérbare sociale subjekter og situationer. Reproduktionsteorien og Gramscis hegemoniteori har to forskellige opfattelser af det folkelige. Studierne af social reproduktion tydeliger, at folkekulturen ikke bare er en manifestation af folkets skabende behov, den er heller ikke udtryk for traditioner, der går forud for industrialiseringen eller resultater af politiske partiers og bevagelsers udnavnelsesmagt. Reproduktionsteorien ser de underordnede klassers handlinger som del af den samlede sociale orden, derved går den langere end blot til at indsamle og registrere sadvaner og afdxkker den komplementare betydning af handlinger, der foregår i forskellige sferer. Det sam- 
fund, der skaber ulighederne pa fabrikken, reprom ducerer dem i skolen, i bylivet, i massemcdierne og i den generelle tilgang til kulturen. Da den samme klasse tildeles underordnede positioner på alle disse områder, kan folkekulturen forstås som resultatet af en forfordeling af de dominerede grupper, hvad angår ekonomiske og kulturelle goder.

Det uhensigtsmæssige ved denne teori $\mathrm{cr}$, at ved at fastlåse de folkelige klasser i dén placering, som den sociale reproduktion tilegner dem, overlader den de herskende klasser alt initiativ. Det er dem, der bestemmer udviklingsretningen, hver enkelt sektors muligheder for tilvækst, samt de kulturelle praksiser, der forener og adskiller parterne i en nation. Man har forsogt at rette op på reproduktivismens almagt med den gramscianske hegemoniteori. Den folkelige kultur er ikke en passiv eller mekanisk effekt af reproduktionen, kontrolleret af de dominerende klasser; den skaber også sig selv, idet den genoptager og bruger traditioner og egne crfaringer fra konflikten med de hegemoniske - snarere end dominerende - krafter. Den klasse, som - selvom den styrer reproduktionen politisk og ideologisk - tillader rum, hvor de underordnede klasser udvikler uafhangige praksiser, der ikke altid er funktionelle for systemet (egne produktions- og forbrugsvaner, udgifter til festdage, som går imod den kapitalistiske akkumulations logik ).

Sammenstillingen af begreberne reproduktion og hegemoni er stadig et ulost problem i samfundsteorien. De, som forsker udfra reproduktionsteorien $\mathrm{i}$ de mest radikale versioner, som Bourdieu, benægter eksistensen af en folkelig kultur. Ifolge Bourdieu er kulturen en kapital, der tilhører hele samfundet $\mathrm{g}$ som alle er fortrolige med gennem habitus. Den ulige fordeling af denne kapital skaber kun kampe pa grund af klasseforskellene. Reproduktionsteorien $\mathrm{cr}$ udviklet i sammenhæng med et homogent kulturelt marked, nemlig det franske, og betragter folkekulturen som et ekko af den dominerende kultur (Bourdicu, 1979 og 1983).

I Frankrig har også forfattere, der deler reproduktionsteoriens anskuelser, stillet sporgsmålstegn ved denne model (f.eks. Grignon og Passeron 1982). I multietniske og flerkulturelle nationer, som de latinamerikanske, kan man argumentere mod eksistensen af en sădan sammenhangende kultur samt eksistensen af dominerende klasser, der forman at fortrange forskelle eller helt underordne sig dem. Men denne kritik eliminerer ikke reproduktivisternes frugtbare analyser af, hvorfor de folkelige klasser ikke øver modstand, men tilpasser sig det system, de tilhorer.

Neogramscianeme ser snarere kulturen som del af en kamp for hegemoni end som et rum for forskelle og politiske konflikter klasserne imellem. Derfor anvendes denne model af dem, der frem hxver de underordnede sektorers autonomi og evne til at tage initiativer og ove modstand. Selvom den komplekse gramscianske opfattelse, beriget af moderne antropologer (Cirese, Lombardi, Satriani, Signorelli), undgår de mest voluntaristiske og spontanistiske tendenser, stimulerer den den type ensidige og utopiske visioner, som vi kritiserede i de »alternative« bevægelser. Vanskelighederne tilspidses såvel i denne strømning som i den reproduktivistiske, när modellerne anvendes som paradigmer, der kan anvise folkelige strategier udfra et postuleret helhedsbillde: Alt hvad der ikke er hegemonisk er underordnet og omvendt. Teorieme fanger ikke tilfæelde, hvor kulturclle bevagelser fra forskellige klasser skaber nye processer, der ikke kan indordnes under betegnelserne hegemonisk eller underordnet, moderne eller traditionel.

\section{Teoretiske modsatninger i definitionen af det folkelige}

Her vil vi pracisere to korsveje i studict af det folkelige, nemlig dels modsxtningen mellem deduktivister og induktivister $\mathrm{pa}$ den ene side og mellem traditionalister og modernister pă den anden.

1. Modsatningen mellem reproduktivisterne og neogramscianerne viser en spanding mellem to grundlaggende videnskabelige traditioner, der berorer al forskning om det folkelige: Jeg tænker her på sammenstødet mellem deduktion og induktion. Dedukivister kalder vi de forskere, der i definitionen af de folkelige kulturer slutter fra det generelle til enkelttilfælde om de karaktertræk, de folkelige kulturer tilfojes af produktionsmåden, imperialismen, den dominerennde klasse, det ideologiske apparat cller kulturindustrien. Visse kommunikationsstudier rasonnerer stadig på denne måde. Deduktivisterne mener, udfra Statens eller massemediernes formodede manipulerende magt, at kunne udlede, hvad der foregår i den folkelige reception. De anerkender ikke, at de underordnede kulturer er autonome eller har en egen måde at forholde sig, kommunikere og gore 
modstand. For deduktivisterne er det eneste, vi ved om de folkelige klasser dét, som de hegemoniske sektorer vil gore imod dem.Induktivisterne går derimod, istudiet af det folkelige, udfra antagelser om, at de underordnede klasser besidder nogle iboende egenskaber eller en kreativitet, som do øvrige sektorer har mistet, eller en modstandskraft, som er basen i deres styrke. Ifolge denne stromning ved viikke mere om de folkelige kultur$\mathrm{cr}$, end hvad de folkelige klasser gor og siger. Opfattelsen af det folkelige som noget iboende gor deres analyser til et sporgsmål om bare at høre, hvad informanterne siger. I fald den interviewede betragter sig selv som indianer, består forskningen $i$ at gengive med hans egne ord, hvad han laver, $i$ mloyalt « at kopiere informantens diskurs; eller hvis han kalder sig arbejder, skal man tro på, at hans klasseforhold og -bevidsthed er, som han prasenterer dem, idet ingen jo ved bedre end han, hvordan det er. Man underkender uoverensstemmelsen mellem tanke og handling og mellem den folkelige klasses selvopfattelse og det, vi kan fa at vide om dens liv ved at studere de sociale lovmessigheder, den lever under. Induktivisteme handler, som om det at indsamle viden handlede om spontant at ophobe data i tilfæeldig rakkefolge, i stedet for at definere de forhold, der giver oplysningerne mening i samfundslogikken.

Modsatningen mellem disse to tendenser viser sig ogsa ved valget af forskningsteknikker. Deduktivisterne foretrakker undersøgelser og statistikker, der gor det muligt at tegne de store linier for massernes adfard. Induktivisterne foretrakker etnografien, feltarbejdet og de åbne interview, fordi de er interesseret $\mathrm{i}$ at registrere det specifikke ved mindre grupper. Grignon og Passeron har observeret, at de valgte teknikker er symptomatiske for måden at betragte den folkelige kulturs forhold til samfundet pá. De, som valger den kvantitative fremgangsmåde, har en tendens til at underkende de folkelige klassers delvise autonomi og understrege deres afhrengighed af de makrosociale love. Modsat plejer de, som frasiger sig makroundersogelserne og -analyserne, at overse dominansforholdene, idet de tilskriver alle klassers handlen en relativ legitimitet.

Denne modsatning kan virke meget skematisk, selvom det er let at komme med eksempler på ren deduktivisme og ren induktivisme. Der findes uden tvivl antropologer, sociologer og kommunikationsforskere, der inddrager komplekse interaktioner mellem det makro- og mikrosociale. Gen- nem feltarbejde og ved at tage kendsgerningernes udfordring op, opnår de at bryde med etnocentrismens og relativismens hypoteser og at få oje på dét, som falder uden for deres oprindelige opfattelse og metoder. Men det er bemxerkelsesværdigt, at vi på trods af disse interaktions-processers äbenbare vigtighed - disponerer over meget få metodiske ressourcer og begreber, der ger det muligt at arbejde med dem.

2. Den anden modsatning indenfor studieme af det folkelige og af de sociale bevagelser, er modsatningen mellem traditionalisterne og modernisterne (modernizadores). Denne modsatning or et symbolsk udtryk for den ulige udvikling af forskellige sektorer i de latinamerikanske samfund. Valget af den ene eller den anden holdning svarer til dels til aktorernes position i samfundsstrukturene. Men denne sociologiske forklaring er ikke tilstræek kelig til at forsta, hvorfor de konceptuelle modsatninger reproducerer de forskellige samfunds- og kultur grupperingers interesser. Hvis vi vil andre på kulturpolitikken og samle den splittede forskning, må vi samarbejde og fordomsfrit fremme objektiviten. Med en fleksibcl, tvardisciplinar forskning, hvor vi accepterer hinandens sandheder, kunne vi bygge bro over kloften mellem folkloristerne og antropologerne på den ene side og sociologerne og kommunikationsforskerne på den anden.

Hvorfor mislykkes sådanne forehavender, selvm om der står god politisk og epistemologisk vilje bag? Noget af svaret findes i analyserne ovenfor. Konflikten mellem tradition og modernitet handler ikke om, at modernisterne dukker op og forsoger at komme traditionalisterne til livs. Den handler heller ikke om, at folket hărdnakket og konstant forsvarer sine traditioner. Der er derimod tale om en gensidig påvirkning: De folkelige bevagelser er interesserede i modernisering, ligeså vel som de hegemoniske sektorer også onsker at bevare det traditionelle, eller en del af det, som en historisk reference og kulturel ressource. Begge parter farr således udbytte deraf. Asymmetrien eksisterer fortsat, men den er mere indviklet end det simple antagonistiske forhold mellem traditionalister og modernister samt underordnede og hegemoniske klasser antyder.

\section{Videnskabelig eller iscenesat definition af det folkelige?}

Hvad er der tilbage efter denne dekonstruktion af 
»det folkelige«? En generende konklusion for forskerne: Det folkelige, et heterogent konglomerat af sociale grupper, har ikke en entydig betydning som videnskabeligt begreb, men derimod teaterforestillingens flertydige betydning. Under betegnelsen »det folkelige placeres bestemte aktører overfor de hegemoniske sektorer, dog ikke nødvendigvis altid i en konfrontation.

Men kan de underste klasser, omdefineret på denne måde, komme til at udgore historiske subjekter og blive mere end blot resultaterne af en iscensattelse? De folkelige scktorer taler og handler i de indfodtes radio, i de lokale aviser, i de folkelige bevagelser i byen samt i sammenslutninger til forsvar af deres interesser i produktion og $\mathrm{i}$ forbrug. Men det ville vare vildledende kun at betragte disse manifestationer som kontrahegemoniske. Man må ikke overse, at selv i de mest selvforanstaltede erfaringer findes handling (acción) og optraden (actuación), der er udtryk for en restituering af dét, man forstår som det agte, sâvel som reproduktion af den dominerende orden. De engelske historikere, samt nogle latinamerikanske, var dem, der bedst opfattede, at ustabiliteten $i$ de folkelige sektorers positioner og forhold ger det umuligt at karakterisere dem praecist. De underordnede grupper or ikke, i virkeligheden, de er derimod under udvikling, fastslår Luis Alberto Romero; derfor cr de ikke et historisk subjekt, men et område i samfundet hvor subjekter konstituerer sig (Romero 1987:15-16).

I denne proces med at rekonstruere det folkelige er det et fremskridt at gå fra en episk iscenesattelse til iscenesattelsen af en tragisk komedie. Den mest vedholdende mangel i karakteristikken af wfolket « har været at betragte de aktører, der samles under denne betegnelse som en social kompakt masse, der gør uophørlige og kampivrige fremskridt mod en ny fremtid. Den mest komplekse forskning viser snarere, at det folkelige kommer til skue, ikke med denne episke ensrettethed, men derimod med den modsætning og flertydighed, der prager dem som både er offer for og udkæmper historiens gang - de som, ligesom i enhver tragikomedie, udvikler de mellemliggende trin, de dramatiske kneb, de parodiske spil, der tillader dem, der ikke har mulighed for radikalt at endre stykkets forløb, at håndtere åbningerne med krcativitet og til egen fordel.

Jeg ser, i den betydning nogle få forfattere tilskriver melodramaet, en vej frem i samfundsvidenskabernes omformulering af det folkelige. Hvorfor er denne dramagenre en af de foretrukne blandt de dominerede klasser? Det, som river de folkelige sektorer med ved tangoen, i telenovelaen og i de populare biograffilm, er, siger Martín-Barbero, genkendelsen og kampen for anerkendelse, behovet for at ty til oprindelige socialformer (slagtskabet, nabosolidariteten, venskabet) overfor det offentliges utilstrakkelige institutionalisering af det sociale, der ikke formair at erstatte txtheden i de folkelige kulturer (Martín-Barbero 1987a:243-44).

Men, hvordan kan man udfore et videnskabeligt arbejde på basis af et så splittet begreb, der anvendes i flxng af folkloristerne, sociologerne og kommunikationsforskerne? Det er et spergsmål, som intet fag alene kan svare på. Hvis der findes en vej frem, tror jeg ikke, at denne kan komme udenom transdisciplinært arbejde. Jeg mener ikke interdisciplinært, fordi dette plejer at betyde, at de forskellige specialister sideordner indhentet viden fragmentarisk og parallelt. De enkelte discipliners abning overfor andre forer til en ubehagelig usikkerhed i studierne af de folkelige kulturer. Men man kan også forestille sig, at det forer forskningen til en interessant periode, hvis vi retter os efter, hvad Italo Calvino sagde om forfatterne:

deres opgave er desto mere attraktiv og vardifuld jo mere usandsynlig, den er, den ideelle bogreol, hvor de kunne tanke sig at blive anbragt, sammen med boger der stadigvak ikke cr vant til at stå ved siden af andre og hvis narhed kunnc skabe elektriske udladninger, kortslutninger (Calvino 1983:208).

Måske er det mest opmuntrende, der sker omkring »det folkelige, at nogle af folkloristerne ikke kun bekymrer sig om at genvinde det, nogle kommunikationsforskere ikke kun om at udbrcde det og nogle politikere ikke kun om at forsvare det. At hver enkelt specialist ikke kun skriver for sine ligestillede, ej heller for at afsige kendelser om, hvad folket er, men derimod snarere for at spørge os selv, sammen med de folkelige bevagelser, om hvordan det kan rekonstrueres.

\section{Litteratur}

Bolléme, Geneviéve (1986) Le peuple par écrit, Paris: Seuil. (Spansk udgave (1990); El pueblo por escrito, Mexico: Grijalbo.

Bourdieu, Pierre (1979) La distinction-Critque sociale du Jugenent. Paris: Minut.

Bourdieu, Pierre (1983) „Vous avez dit populaire? Actes de la Recherche en Sciences Sociales, no. 46. 
Calvino, Italo (1983) Punto y aparte. Ensayos sobre literaturay sociedad, Barcelona: Bruguera.

Ganclini, Néstor Garcia og Rafael Roncagliolo eds. (1988) Cultura transnacional y culturas populares, Lima: IPAL.

Clifford, J. og G. Marcus eds. (1986) Writing Culture: The Potics and Politics of Elnography, Berkeley: The University of Califormia Press.

Ford, Anibal (1988) »Las fisuras de la industria culturalk in Altemativa Latinoamericana.

Foucault, Michael (1977) Historia de la sexwalidad 1. La voluntad de saber, Mexico: Siglo XIX.

Grignon, Claude og Jean Claude Passeron (1982) Sociologie de la culure at sociologie des cultures populaires, Paris: Gides.

Gullar, Ferreira (1980) „Cultura posta en questaow in Arte en Revista, vol. 2, no. 3.

Martín-Barbero, Jesús (1987) »Imnovación tecnológica y transformación cultural in Telos, no. 9, Madrid.

Martín-Barbero, Jesús (1987) De los medios a las mediaciones, Comunicacion, cultura y hegemonia, Barcelona: G. Guli
Monsiváis, Carlos (1984) wotas sobre el Estado, la cultura nacional y las culturas populares in Cuademos polhiros, no. 30 .

Portantiero, Juan Carlos og Emilio de I pola (1987) "Lo nacional popular y los populismos realmente existentes in Nueva Sociedad, maj-juni.

Romero, Louis Alberto (1987) Los sectores populares urbanos como sujetos histónicos, Buenos Aires, CISEA-PEHESA.

Rosaldo, Renato (1989) Culture and Truth, Stanford: Stanford University Press.

Solanas, Fernando og Octavio Getino (1979), Cine, cultura y descolonizacion, Mexico: Siglo XXI.

Vega Centeno, Imelda (1985) Agrarismo popular" mito, cultura historia, Lima: Tarea.

Verón, Eliseo (1987) La semiosis social, Buenos Aires: Gedisa.

Néstor Garcia Canclini er antropolog, ansat pă Mexico Universitetet, Mexico City. Én af de forende tænkere indenfor kultur- og medieforskning i Latinamerika. 